\title{
Use of Oxamyl for the Control of the Nematodes in Yam (Dioscorea rotundata Poir) ${ }^{1}$
}

\author{
J. Román, D. Oramas, and J. Green ${ }^{2}$
}

\begin{abstract}
Two field trials were performed to evaluate oxamyl $24 \mathrm{~L}$ for control of nematodes and increase yields of high quality yam tubers, Dioscorea rotundata Poir. The nematicide was tested as a seedpiece immersion, furrow and foliar treatment, as well as combinations of foliar with seedpiece and furrow treatments. Significant increases on yield of high quality yams were obtained by controlling nematodes with the combination of the foliar and seedpiece treatments and with the seedpiece treatment alone. Oxamyl $24 \mathrm{~L}$, if registered for use in yams in Puerto Rico, can provide the farmer an effective alternative to the presently authorized granular nematicide aldicarb $10 \mathrm{G}$.
\end{abstract}

\section{INTRODUCTION}

Yam (Dioscorea spp.) is the most important starchy food crop cultivated in Puerto Rico. Several nematodes, such as the yam and lesion nematodes, reduce yield and quality of the tubers causing significant losses to growers $(1,2,4,5)$. Symptoms of nematode damage to yam tubers have been described elsewhere $(2,7)$. Several investigators $(1,3,8)$ have demonstrated the efficacy of soil treatments with various granular nematicides in controlling nematodes in yam. Oxamyl $24 \mathrm{~L}$, a liquid nonfumigant nematicide, has been evaluated in yams as a seedpiece or tuber immersion treatment $(7,8)$ and as a foliar treatment $(5)$. This paper presents results of field experiments where oxamyl $24 \mathrm{~L}$ was evaluated as a seedpiece, furrow and foliar treatment, as well as combinations of the three treatments.

\section{MATERIALS AND METHODS}

A field of an Ultisol soil ( $\mathrm{pH} 4.6$, clay $42.4 \%$, sand $29.6 \%$, silt $28.9 \%$ and organic matter 2.2.\%) at the Corozal Agricultural Experiment Substation, predominantly infested with Pratylenchus coffeae and Rotylenchulus sp., was selected to conduct two trials, one during the spring of 1981 and one during the spring of 1982. Tuber pieces of white yam, Dioscorea rotundata, of approximately $227 \mathrm{~g}$ and infected with $P$. coffeae, were planted in $6.75 \mathrm{~m}^{2}$ plots at $0.45 \times 1.5 \mathrm{~m}$. Oxamyl $24 \mathrm{~L}$ treatments were as follows: 1) immersion of the seedpiece in $2,400 \mathrm{p} / \mathrm{m}$ (a.i.) for 15 min; 2) a furrow application of $18.6 \mathrm{~L} /$ ha before planting; 3 ) foliar

${ }^{1}$ Manuscript submitted to Editorial Board October 6, 1983.

${ }^{2}$ Nematologist, Assistant Nematologist and Assistant Horticulturist, respectively, Agricultural Experiment Station, College of Agricultural Sciences, Mayagüez Campus, University of Puerto Rico. 
applications of $4.9 \mathrm{~L} /$ ha at a 15 -day interval; 4) combination of seedpiece and foliar treatments; 5) combination of foliar and furrow treatments; and 6) an untreated check. The treatments were replicated four times in a partially balanced incomplete block design. For seedpiece treatment, tuber pieces were placed in a cloth bag, dipped for $15 \mathrm{~min}$ in a container in which the oxamyl had been diluted in 25 gal of water. The seedpieces were planted the following day. Knapsack applicators, 5 gal capacity, were used for application of diluted commercial oxamyl as furrow and foliar treatments. Oxamyl L diluted in 2 liters of water per plot was sprayed over the open furrow and seedpieces planted and covered immediately with soil. Foliar treatments were started 2 to 3 months after planting or when enough green foliage had developed, and discontinued when foliage showed the first symptoms of senescence. Ten applications (at a 2-week interval) were made in 1981 and 12 in 1982. The amount of water for the dilution of oxamyl $\mathrm{L}$ in the foliar sprays varied from about $750 \mathrm{ml}$ per plot during early treatments to $2,000 \mathrm{ml}$ for the late applications. Soil samples for nematode determination were taken before treatment; 4 to 5 months after planting; and at harvest. The Christie and Perry method for extracting nematodes (6) was used in the laboratory to determine the nematodes present in $250 \mathrm{~cm}^{3}$ of soil. The extracted nematodes were counted under a dissecting microscope, amounts of nematodes averaged and percentage of nematode control calculated. One month after emergency, plants were applied an 8-8-13 fertilizer at the rate of $1,120 \mathrm{~kg} / \mathrm{ha}$. Weeds were controlled with a mixture of Ametryn and Paraquat. Foliar diseases were controlled with Benomyl whenever needed. Data obtained was subjected to analysis of variance. Yam samples were sent to DuPont Co. for residue determination.

\section{RESULTS AND DISCUSSION}

In both years significant yield increases of high quality yams were obtained with the combination of the seedpiece and foliar treatments (11.9 and 6.09 tons/ha, respectively). Nematode control in soil for both years were 61 and $80 \%$, respectively (table 1 ). These results agree with those reported by Badra et al. (5) in fields infested with Meloidogyne javanica and Pratylenchus brachyurus. Also, in 1982 significant increases on yield of high quality tubers were obtained with the seedpiece treatment alone (4.38 ton/ha). In 1982 nematode control was 55\%. Other investigators have also demonstrated the efficacy of the seedpiece treatment. Coates-Beckford (7) found that immersion of tubers in 1,200 and 2,400 $\mathrm{p} / \mathrm{m}$ of oxamyl for $30 \mathrm{~min}$ were the most successful treatments for controlling $P$. coffeae and obtaining viable planting material. Badra and Caveness (4) reported significantly increased tuber yields of $D$. alata by 
TABLE 1.-Average yield of high quality yams (Dioscorea rotundata) and percent control of nematodes in soil after nematicide treatments

\begin{tabular}{|c|c|c|c|c|}
\hline \multirow[b]{2}{*}{ Oxamyl $24 \mathrm{~L}$ treatments } & \multicolumn{2}{|c|}{1981} & \multicolumn{2}{|c|}{1982} \\
\hline & $\begin{array}{l}\text { Metric } \\
\text { tons/ha }\end{array}$ & $\begin{array}{l}\text { Nematode } \\
\text { control }^{1}\end{array}$ & $\begin{array}{l}\text { Metric } \\
\text { tons/ha }\end{array}$ & $\begin{array}{c}\text { Nematode } \\
\text { control }\end{array}$ \\
\hline & & $\%$ & & $\%$ \\
\hline \multicolumn{5}{|l|}{ 1. Seed-piece } \\
\hline$(2,400 \mathrm{p} / \mathrm{m}$ a.i. $/ 15 \mathrm{~min})$ & 5.9 & 13 & $4.38^{*}$ & 55 \\
\hline \multicolumn{5}{|l|}{ 2. Furrow } \\
\hline (18.6 1/ha before planting) & 4.8 & 19 & 1.66 & 50 \\
\hline \multicolumn{5}{|l|}{ 3. Foliar } \\
\hline (4.9 1/ha every 2 weeks) & 9.6 & 19 & 2.15 & 78 \\
\hline 4. Seedpiece + foliar (combined) & $11.9^{* 2}$ & 61 & $6.09^{* * 3}$ & 80 \\
\hline 5. Furrow + foliar (combined) & 9.6 & 53 & 2.84 & 91 \\
\hline 6. Check & 4.1 & 0 & 0.03 & 0 \\
\hline
\end{tabular}

${ }^{1}$ Based on average of three soil samples consisting mainly of $P$. coffeae and Rotylenchulus sp.

${ }^{2}$ Significant difference $(5 \%)$ over check.

${ }^{3}$ Significant difference $(1 \%)$ over check.

TABLE 2.-Residual concentrations of oxamyl and oxime fragments (desmethylcarbamate fragments, DMCF) in yam tubers

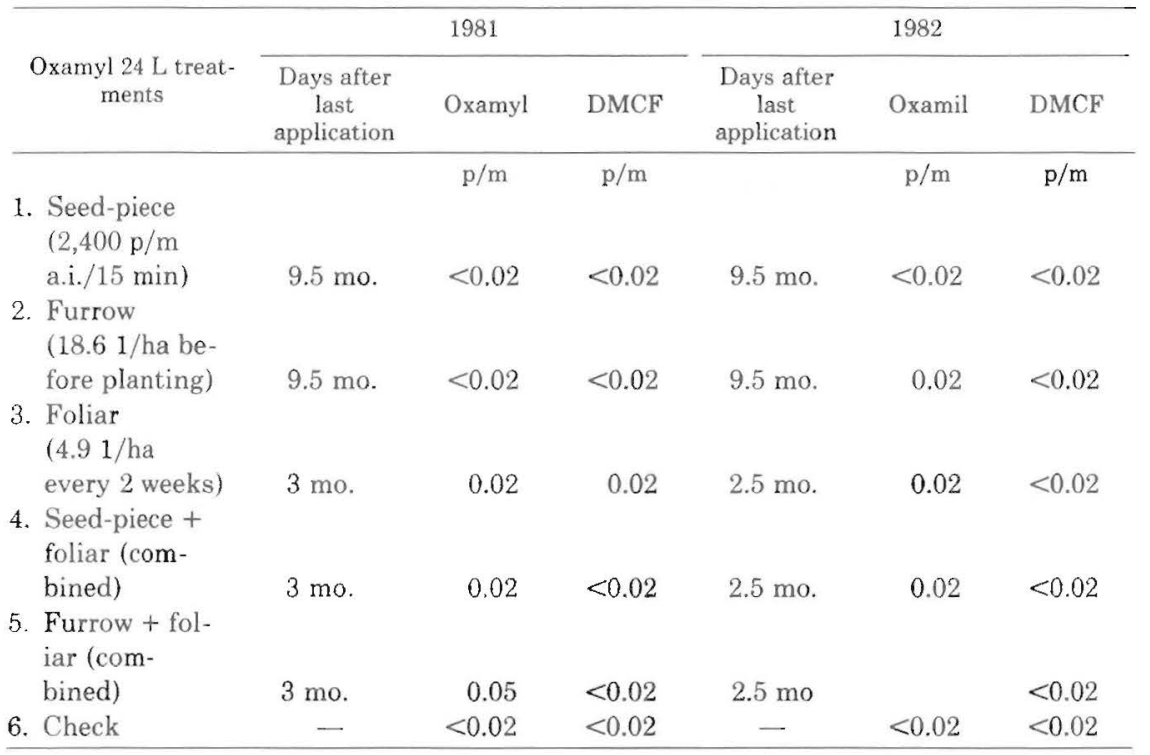

controlling Scutellonema bradys after immersion of tubers in an aqueous solution of oxamyl $10 \mathrm{G}$ at $1,000 \mathrm{p} / \mathrm{m}$ for $30 \mathrm{~min}$.

Table 2 gives residual concentrations of oxamyl and its oxime fragments (DMCF) for the two field trials. The data revealed that the 
accumulated toxic residues were below the $0.1 \mathrm{p} / \mathrm{m}$ E.P.A. established tolerance level of oxamyl for the four representative crops of the roottuber group (carrot, potato, sugarbeet and radish). This information will be of great value for the registration of the use of oxamyl in yam in Puerto Rico.

The data presented here indicate that a combination of seedpiece and foliar treatments, as well as a seedpiece immersion in the nematicide results in high yields of high quality yams. If registered for use in yam, oxamyl $24 \mathrm{~L}$ may represent an alternative chemical treatment to aldicarb 10G, which has been registered for use in yams in Puerto Rico.

\section{RESUMEN}

Se realizaron dos pruebas de campo para evaluar el efecto de oxamyl $24 L$ para combatir nematodos e incrementar la producción de ñames, Dioscorea rotundata Poir de alta calidad. Este nematicida se evaluó como tratamiento de inmersión para la semilla, tratamientos al surco y al follaje y combinaciones del tratamiento al follaje con los tratmientos a la semilla y al surco. Al aplicar oxamyl 24L al follaje en combinación con el tratamiento de la semilla y con el tratamiento a la semilla solamente se obtuvieron aumentos significativos en el rendimiento de ñames de alta calidad.

Si se lograra conseguir una autorización para usar oxamyl 24 L para ñames en Puerto Rico se proveería al agricultor con otro producto eficaz contra los nematodos, además del producto granulado (aldicarb 10G) que actualmente puede usarse.

\section{LITERATURE CITED}

1. Adesiyan, S. O. and Badra, T., 1982. Granular nematicides for control of the yam nematode, Scutellonema bradys, and relevant residues in raw tubers, J. Nematol. 14: 213-16.

2. Acosta, N. and Ayala, A., 1975. Pathogenicity of Pratylenchus coffeae, Scutellonema bradys, Meloidogyne incognita, and Rotylenchulus reniformis in Dioscorea rotundata, J. Nematol. 7: 1-6.

3. - and - 1971. Observations on yam (Dioscorea alata) nematodes, Nematropica 1: $39-40$.

4. Badra, T. and Caveness, F. E., 1979. Chemotherapy of Dioscorea alata for disinfection of Scutellonema bradys, Nematropica 9: 135-37.

5. Steel, W. M. and Caveness, F. E., 1980. The employment of a non-fumigant nematicide for control of the root-knot and lesion nematodes in yams and crop preservation in storage, Nematropica 10: 81-5.

6. Christie, J. R. and Perry, V. G., 1951. Removing nematodes from soil, Proc. Helminthol. Soc. Wash. 18: 106-08.

7. Coates-Beckford, P. L., 1977. Comparison of various treatments for the control of Pratylenchus coffeae in yam, Nematropica 7:20-6.

8. Román, J., Oramas, D. and Green, J., 1980. Investigations on the control of yam (Dioscorea rotundata) nematodes, Nematropica 10: 71-2. 